\title{
Rates of biogeochemical phosphorus and copper redistribution in young floodplain soils
}

\author{
F. Zehetner, G. J. Lair, M. Graf, and M. H. Gerzabek \\ Institute of Soil Research, University of Natural Resources and Applied Life Sciences, Peter-Jordan-Str. 82, \\ 1190 Vienna, Austria
}

Received: 25 August 2009 - Published in Biogeosciences Discuss.: 2 October 2009

Revised: 2 December 2009 - Accepted: 3 December 2009 - Published: 10 December 2009

\begin{abstract}
Nutrients and trace metals in river-floodplain systems may originate from anthropogenic activities and/or geogenic sources. Here, we analyze a soil chronosequence (2 to approximately 600 years) on a floodplain at the Danube River (Austria) to quantify the rates of $\mathrm{P}$ and $\mathrm{Cu}$ redistribution among biogeochemical pools during early soil formation under temperate continental climate. While bulk and clay mineralogy remained unchanged over the studied age gradient, we found considerable (mostly non-linear) redistribution of $\mathrm{P}$ and $\mathrm{Cu}$ among biogeochemical pools. The calcium-associated $\mathrm{P}$ and $\mathrm{Cu}$ fractions decreased rapidly during the initial decades of soil formation. The dissolution of calcium-associated $\mathrm{P}$ was mirrored by marked accumulation of organic P. Copper incorporated within resistant minerals showed a relative enrichment with soil age. The mean dissolution rates of calcium-associated (primary mineral) P decreased exponentially with increasing soil age from $\sim 1.6 \mathrm{~g} \mathrm{~m}^{-2} \mathrm{yr}^{-1}$ over $\sim 15$ years to $\sim 0.04 \mathrm{~g} \mathrm{~m}^{-2} \mathrm{yr}^{-1}$ over $\sim 550$ years, and were almost an order of magnitude higher than rates reported for tropical environments. Our study demonstrates that on riverine floodplains, rapid biogeochemical transformations can occur within the first centuries of soil formation under temperate climatic conditions.
\end{abstract}

\section{Introduction}

The uppermost layer of earth's crust progressively changes over time through the actions of weathering and soil formation. Soil studies across substrate age gradients (chronosequences; Huggett, 1998) have enhanced our understanding of weathering rates under various environmental conditions.

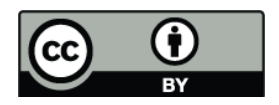

Correspondence to: G. J. Lair (georg.lair@boku.ac.at)
Most chronosequence studies in fluvial environments have covered thousands to millions of years, and depending on the climatic regime, the following trends were observed with increasing soil age: mineralogical changes (Dorronsoro and Alonso, 1994) combined with specific surface area increase (White et al., 1996); pH decrease (Vidic and Lobnic, 1997); increasing clay accumulation, clay translocation, and rubification (Dorronsoro and Alonso, 1994; Engel et al., 1996; Leigh, 1996; Vidic and Lobnic, 1997); accumulation of pedogenic carbonate (Eash and Sandor, 1995; Nordt et al., 1998) and silicon (Kendrick and Graham, 2004); increase of $\mathrm{Fe}$ oxide contents (Dorronsoro and Alonso, 1994; Engel et al., 1996; Leigh, 1996) and crystallinity (Shaw et al., 2003; Kendrick and Graham, 2004).

By comparison, only few studies have covered the initial stages of weathering and soil formation on floodplains. Generally, they report rapid (decadal-scale) accumulation of soil organic $\mathrm{C}$ and $\mathrm{N}$, which leveled off during the following centuries of pedogenesis (e.g. van Cleve et al., 1993; Kaye et al., 2003; Adair et al., 2004).

In previous studies on a young floodplain at the Danube River in Austria, we found trends of P transformation (Zehetner et al., 2008) and sorption (Lair et al., 2009a) as well as $\mathrm{Cu}$ and $\mathrm{Cd}$ retention (Graf et al., 2007; Lair et al., 2008) along with changes of Fe oxide crystallinity. More recently, we linked $\mathrm{Fe}$ oxide crystallinity to measured soil age (Lair et al., 2009b), which allows calculation of process rates. We then used this approach to estimate the rates of organic matter accretion during early pedogenesis in these soils (Zehetner et al., 2009).

Nutrients and trace metals may become pollutants in fluvial environments (e.g. Du Laing et al., 2009; Lair et al., $2009 \mathrm{c}$ ). Besides anthropogenic pollutant sources (see for example Lair et al., 2009c), also geogenic sources may contribute to the contamination of river-floodplain systems. The most dramatic example of the latter is probably the arsenic

Published by Copernicus Publications on behalf of the European Geosciences Union. 
calamity in parts of India and Bangladesh (e.g. Mukherjee and Bhattacharya, 2001).

To date, the release of geogenic nutrients and trace metals in river-floodplain systems is still poorly understood and rarely quantified. For an improved risk assessment in fluvial environments, it is therefore essential to enhance our knowledge on the rates of geogenic contaminant release and redistribution among biogeochemical pools of different mobility and bioavailability. In the present study, we selected $\mathrm{P}$ and $\mathrm{Cu}$ as proxies for nutrients and trace metals, respectively, and quantify their rates of redistribution among biogeochemical pools during the first centuries of floodplain soil formation, in which the soils are still in intimate contact with groundwater and river water.

\section{Study area}

\subsection{Geological and climatic setting}

The study area is located in the Danube floodplain downstream of Vienna, Austria (Fig. 1). During the Alpine glaciations, the Danube River has continuously incised into the uplifted Tertiary fill of the Vienna basin and accumulated meltwater terraces (Decker et al., 2005). The recent floodplain consists of up to $20 \mathrm{~m}$ gravel covered by fine sediments. The present main channel of the Danube River was created by a channelization between 1870 and 1875, and a flood-control dike was constructed between 1882 and 1905 (Lair et al., 2009c). The study area experiences a continental climate with hot summers and cold winters (Fig. 1). The mean annual temperature (MAT) is approximately $9^{\circ} \mathrm{C}$, the mean annual precipitation (MAP) approximately $550 \mathrm{~mm}$, and the mean annual potential evapotranspiration approximately $570 \mathrm{~mm}$.

\subsection{Study sites and soil sampling}

We used a chronosequence approach to follow floodplain soil development. Our chronosequence included young river islands (e.g. site 1; Fig. 1 and Table 1), areas periodically inundated by flood events (e.g. sites 5, 6), and areas disconnected from the river for approximately 100 years through the flood-control dike (e.g. sites 7, 9, 10). We sampled three soil profiles at each site using an $80-\mathrm{mm}$ core drill. Core samples were taken down to $60 \mathrm{~cm}$ and divided into 5 and 10-cm depth layers. The age of individual soil depth layers was estimated using a chronofunction that relates $\mathrm{Fe}$ oxide crystallinity in the soils $\left(\mathrm{Fe}_{\mathrm{o}} / \mathrm{Fe}_{\mathrm{d}}\right)^{1}$ to soil age measured with ${ }^{137} \mathrm{Cs}$ and optically stimulated luminescence (Fig. 2; Lair et al., 2009b). The studied soil profiles revealed various episodes of sediment deposition and soil formation. Yet,

\footnotetext{
${ }^{1}$ Iron in crystalline and non-crystalline hydrous oxides was extracted with dithionite-citrate-bicarbonate $\left(\mathrm{Fe}_{\mathrm{d}}\right.$; Mehra and Jackson, 1960), and iron associated with amorphous constituents was extracted with acid ammonium oxalate ( $\mathrm{Fe}_{\mathrm{o}}$; Schwertmann, 1964).
}

the topsoil layers down to at least $20 \mathrm{~cm}$ depth showed relatively uniform deposition ages (Lair et al., 2009b). In the present study, we used composite samples from 0 to $10 \mathrm{~cm}$ depth, whose deposition ages ranged from 2 years (site 1) to approximately 600 years (site 10 ).

\subsection{Basic soil characteristics}

In the studied soils, bulk mineralogy revealed mixed contributions of calcite, dolomite, quartz, plagioclase, K-feldspar and mica, and clay mineralogy was dominated by illite and chlorite (Haslinger et al., 2006). Neither bulk mineralogy nor clay mineralogy showed a consistent age trend across the studied chronosequence. Likewise, the soils' carbonate contents showed little variation and no consistent age trend (Zehetner et al., 2008; cf. Table 1). Soil pH varied in a narrow range (above neutral) between sites; however, organic $\mathrm{C}$ (OC) contents were strongly influenced by soil age and land use (Zehetner et al., 2009; cf. Table 1).

In the studied fluvial environment, soil grain size distribution showed marked differences between different geomorphic positions. The island soils had coarse textures with low clay contents (Lair et al., 2009b; cf. Fig. 1, Table 1), comparable to the grain size distribution of suspended flood sediments in the Danube main channel (Zehetner et al., 2008). Conversely, the soils on the floodplain had considerably finer textures (Lair et al., 2009b; cf. Fig. 1, Table 1). The observed differences are a result of different sedimentation conditions, with decreasing flow velocities of flood water allowing finer particles to settle.

\section{Methods}

\subsection{Phosphorus extraction}

Phosphorus extraction was performed according to the SMT protocol (Standards, Measurements and Testing Programme of the European Commission; Pardo et al., 2003) using airdried, finely ground soil samples. (1) One 200-mg sample aliquot was extracted with $20 \mathrm{~mL}$ of $1 \mathrm{M} \mathrm{NaOH}$ for $16 \mathrm{~h}$. A $10 \mathrm{~mL}$ aliquot of the supernatant was acidified with $4 \mathrm{~mL}$ of $3.5 \mathrm{M} \mathrm{HCl}$ to precipitate humic substances. After $16 \mathrm{~h}$, NaOH-extractable inorganic P (IP) was determined in the remaining supernatant. The residue of the $\mathrm{NaOH}$ extraction was extracted with $20 \mathrm{~mL}$ of $1 \mathrm{M} \mathrm{HCl}$ for $16 \mathrm{~h}$, and $\mathrm{HCl}$ extractable IP was determined in the extract. This fraction represents calcium-associated (primary mineral/apatite) P (Williams et al., 1976, 1980). (2) A second 200-mg sample aliquot was extracted with $20 \mathrm{~mL}$ of $1 \mathrm{M} \mathrm{HCl}$ for $16 \mathrm{~h}$, and the residue was placed in a porcelain crucible and calcined at $450^{\circ} \mathrm{C}$ for $3 \mathrm{~h}$, then extracted again with $20 \mathrm{~mL}$ of $1 \mathrm{M} \mathrm{HCl}$ for $16 \mathrm{~h}$ to determine organic $P(\mathrm{OP})$. Extracted phosphate was measured spectrophotometrically using the molybdenum blue method according to Murphy and Riley (1962) (detection limit: $0.3 \mathrm{mg} \mathrm{PL}^{-1}$ ). 
Table 1. Basic site and soil characteristics. Soil depth $0-10 \mathrm{~cm}, n=3$ except for clay and sand $(n=1)$ and $\Sigma \mathrm{P}_{\text {extracted }}(n=2)$; $\mathrm{BD}=$ bulk density; $\mathrm{OC}=$ organic $\mathrm{C} ; \Sigma \mathrm{P}_{\text {extracted }}=$ sum of $\mathrm{NaOH}$-extractable inorganic $\mathrm{P}, \mathrm{HCl}$-extractable inorganic $\mathrm{P}$, and organic $\mathrm{P}$ (Pardo et al., 2003); $\Sigma \mathrm{Cu}_{\text {extracted }}=$ sum of 5 sequentially extracted $\mathrm{Cu}$ fractions according to Tessier et al. (1979). Letters a,b indicate significantly different means (0.05 level, Scheffé test). Values in parentheses are standard deviations.

\begin{tabular}{|c|c|c|c|c|c|c|c|c|c|c|c|}
\hline Site & Land use & $\begin{array}{l}\text { Inundation } \\
\text { frequency } \\
\left(\mathrm{d} \mathrm{yr}^{-1}\right)\end{array}$ & $\begin{array}{c}\text { Soil age } \\
(\mathrm{yr})\end{array}$ & $\begin{array}{c}\mathrm{BD} \\
\left(\mathrm{g} \mathrm{cm}^{-3}\right)\end{array}$ & $\begin{array}{c}\operatorname{Sand}^{(3)} \\
(\%)\end{array}$ & $\begin{array}{c}\text { Clay }^{(3)} \\
(\%)\end{array}$ & $\begin{array}{c}\mathrm{pH} \\
\left(\mathrm{H}_{2} \mathrm{O}\right)^{(3)}\end{array}$ & $\begin{array}{c}\mathrm{OC}^{(4)} \\
(\%)\end{array}$ & $\begin{array}{c}\mathrm{CaCO}_{3}^{(3)} \\
(\%)\end{array}$ & $\begin{array}{l}\Sigma \mathrm{P}_{\text {extracted }} \\
\left(\mathrm{mg} \mathrm{kg}^{-1}\right)\end{array}$ & $\begin{array}{c}\Sigma \mathrm{Cu}_{\text {extracted }} \\
\left(\mathrm{mg} \mathrm{kg}^{-1}\right)\end{array}$ \\
\hline 1 & Woodland & $130-150$ & $2^{\#}$ & $1.06(0.07)$ & 40.5 & 11.3 & $7.29(0.08)$ & $0.79(0.16)$ & $19.0(3.3)$ & $684(100)^{\mathrm{a}}$ & $21.5(6.4)^{\mathrm{a}}$ \\
\hline 5 & Forest & $5-10$ & $18(6)$ & $1.59(0.23)$ & 22.0 & 27.1 & $7.35(0.07)$ & $2.66(0.15)$ & $25.1(1.3)$ & $714(2)^{\mathrm{a}}$ & $35.4(1.4)^{\mathrm{b}}$ \\
\hline 6 & Grassland & $1-2$ & $140(80)$ & $1.96(0.13)$ & 13.0 & 29.8 & $7.29(0.10)$ & $3.28(0.31)$ & $26.5(1.5)$ & $602(52)^{\mathrm{a}}$ & $27.0(1.5)^{\mathrm{a}, \mathrm{b}}$ \\
\hline 7 & Grassland & 0 & 131 (77) & $1.80(0.16)$ & 16.3 & 30.1 & $7.34(0.01)$ & $4.18(0.51)$ & $26.4(0.4)$ & $670(21)^{\mathrm{a}}$ & n.d. \\
\hline 9 & Forest & 0 & $332(75)$ & $0.97(0.06)$ & 15.6 & 38.0 & $7.50(0.16)$ & $3.10(0.29)$ & $25.1(1.5)$ & $690(4)^{\mathrm{a}}$ & $25.7(2.2)^{\mathrm{a}}$ \\
\hline 10 & Grassland & 0 & 505 (91) & $0.89(0.15)$ & 19.0 & 30.4 & $7.44(0.02)$ & $5.87(0.34)$ & $18.8(1.2)$ & $761(12)^{\mathrm{a}}$ & $29.4(2.3)^{\mathrm{a}, \mathrm{b}}$ \\
\hline
\end{tabular}

(1) C. Baumgartner (National Park Donau-Auen GmbH, personal communication, 2009)

(2) according to Lair et al. (2009b)

(3) determined according to Soil Survey Staff (2004)

(4) calculated as the difference of total and carbonate C; total C quantified by dry combustion (Tabatabai and Bremner, 1991)

\# deposited during a 100-year-return flood in 2002

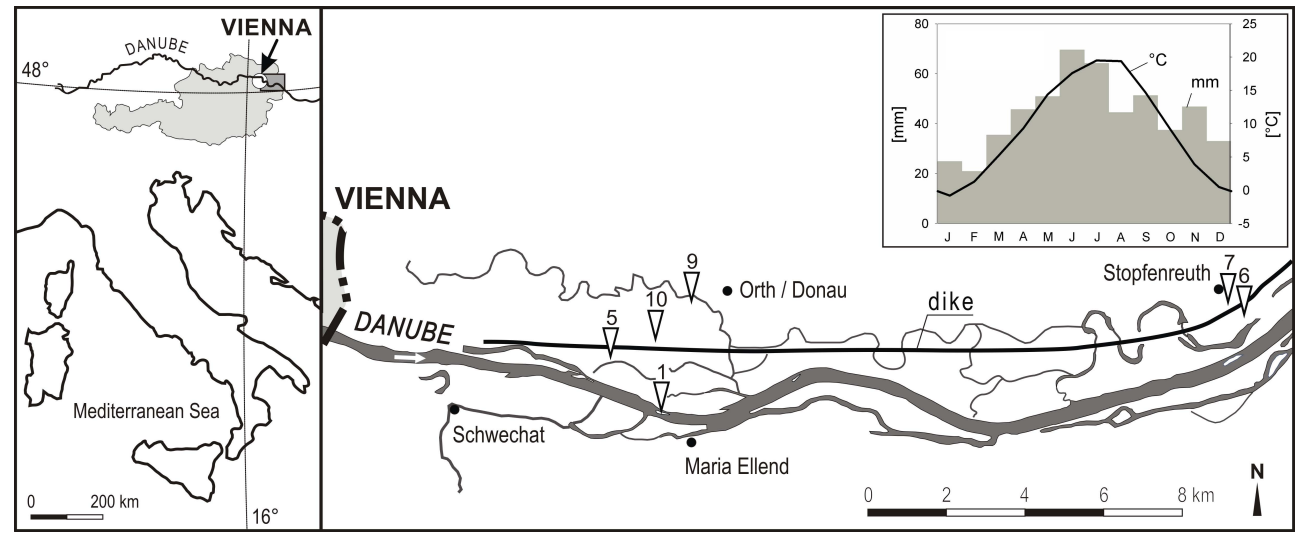

Fig. 1. Study area with climate diagram; triangular markers indicate sampling sites representing a soil chronosequence; numbering in accordance with Lair et al. (2009b).

\subsection{Copper extraction}

Sequential extraction of $\mathrm{Cu}$ was conducted according to the protocol developed by Tessier et al. (1979) and slightly modified by Vanek et al. (2005), in which $1.00 \mathrm{~g}$ of soil is sequentially subjected to the following extraction steps. (A) $8 \mathrm{~mL}$ of $1 \mathrm{M} \mathrm{MgCl}_{2}$ at $\mathrm{pH} 7$ (exchangeable, weakly sorbed); (B) $8 \mathrm{~mL}$ of $1 \mathrm{M} \mathrm{NaOAc}$ at $\mathrm{pH} 5$ (sorbed or carbonate-bound); (C) $20 \mathrm{~mL}$ of $0.04 \mathrm{M} \mathrm{NH}_{2} \mathrm{OH} \cdot \mathrm{HCl}$ in $25 \% \mathrm{HOAc}$ (strongly bound to easily reducible $\mathrm{Mn}$ oxides and amorphous $\mathrm{Fe}$ oxides); (D) $3 \mathrm{~mL}$ of $0.02 \mathrm{M} \mathrm{HNO}_{3}$ and $5 \mathrm{~mL}$ of $30 \% \mathrm{H}_{2} \mathrm{O}_{2}$ at $\mathrm{pH} 1.5$ (very strongly bound or incorporated into organic matter or other oxidizable species); (E) $20 \mathrm{~mL}$ of $65 \% \mathrm{HNO}_{3}$ at $140^{\circ} \mathrm{C}$ for at least $3 \mathrm{~h}$ (incorporated within resistant minerals). After each extraction step, an aliquot of the supernatant was removed with a pipette and stored in a polyethylene bottle to which $0.5 \mathrm{~mL}$ of $65 \% \mathrm{HNO}_{3}$ was added for sample preservation. The remainder of the extract was discarded, and the residue was washed with $4 \mathrm{~mL}$ of distilleddeionized water, which was discarded after centrifuging. Extracted $\mathrm{Cu}$ was measured with flame atomic absorption spectroscopy (detection limit: $0.01 \mathrm{mg} \mathrm{L}^{-1}$ ).

\subsection{Statistical analyses}

Statistical analyses were performed using the SPSS 16 software package for Windows (Bühl, 2008). Correlations between variables were calculated with the Pearson correlation coefficient. One-way analysis of variance (ANOVA) with Scheffé's post-hoc test was used for comparison of means (Mann, 2007). 


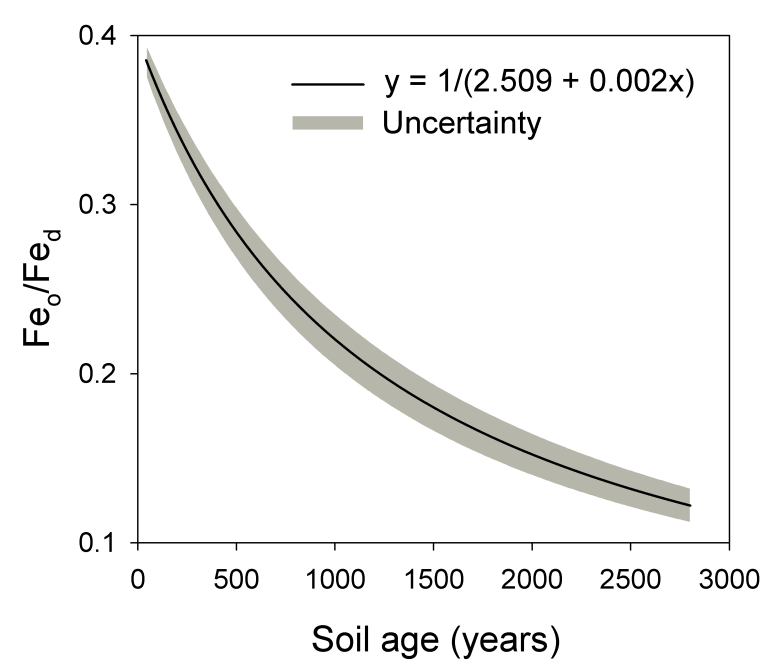

Fig. 2. Chronofunction model relating iron oxide crystallinity $\left(\mathrm{Fe}_{\mathrm{o}} / \mathrm{Fe}_{\mathrm{d}}\right)$ to soil age measured with ${ }^{137} \mathrm{Cs}$ and optically stimulated luminescence (Lair et al., 2009b); $\mathrm{Fe}_{\mathrm{o}}=$ oxalate-extractable $\mathrm{Fe}$; $\mathrm{Fe}_{\mathrm{d}}=$ dithionite-extractable $\mathrm{Fe}$.

\section{Results and discussion}

\subsection{Temporal redistribution of phosphorus among biogeochemical pools}

The sum of extracted $\mathrm{P}(\mathrm{NaOH}-$ extractable IP, HClextractable IP, OP) did not change significantly within 600 years of pedogenesis and varied between approximately 600 and $750 \mathrm{mg} \mathrm{kg}^{-1}$ (Table 1), which is comparatively high and characteristic of young and slightly weathered soils (Cross and Schlesinger, 1995). We did not find elevated soil P levels in areas between the river and the flood-control dike compared to areas outside the dike (Table 1, Fig. 1), which shows that anthropogenic $\mathrm{P}$ release during the last century has not resulted in increased $\mathrm{P}$ levels on the recent floodplain. The majority of $\mathrm{P}$ in the studied soils is likely of geogenic origin.

The distribution of $\mathrm{P}$ among biogeochemical pools showed distinctive changes with soil age (Fig. 3). In the young soils, $\mathrm{HCl}$-extractable IP was the dominant fraction with minor portions of OP and $\mathrm{NaOH}$-extractable IP (Fig. 3). However, during the initial 100 years of soil formation, $\mathrm{HCl}$-extractable IP dissolved rapidly while OP increased markedly. The trends of OP and HCl-extractable IP intersect after approximately 150 years and continuously level off during the following centuries of pedogenesis. Conversely, $\mathrm{NaOH}-$ extractable IP did not show a significant age trend and remained at low levels throughout the chronosequence (Fig. 3).

The trend of dissolving primary mineral $\mathrm{P}(\mathrm{HCl}-$ extractable IP) and concomitant build-up of OP through primary succession in the early stages of soil formation corresponds with Walker and Syers' (1976) conceptual model of $\mathrm{P}$ transformation during pedogenesis and with the observations of Crews et al. (1995) across a chronosequence in

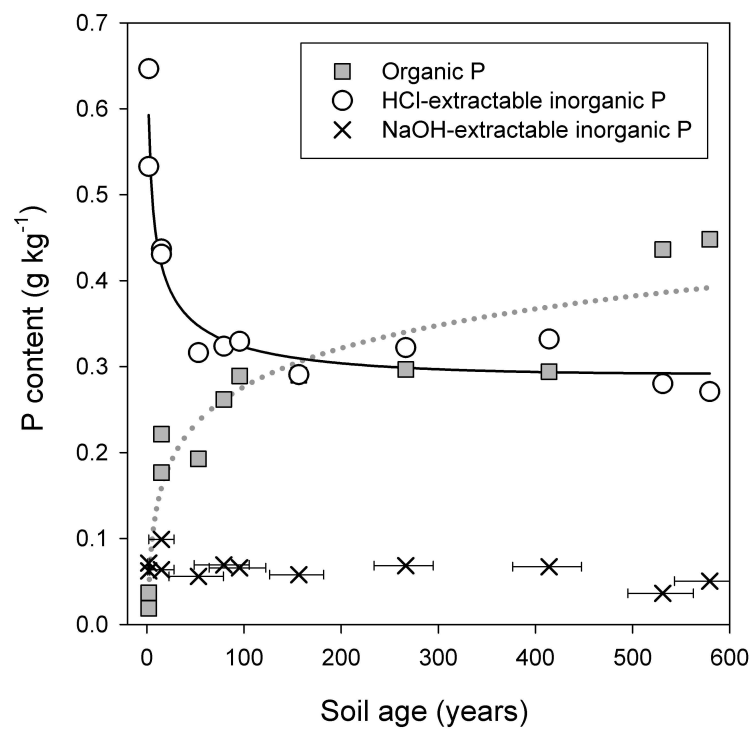

Fig. 3. Distribution of phosphorus among biogeochemical pools along the floodplain soil chronosequence $(0-10 \mathrm{~cm}$ depth); P extraction according to Pardo et al. (2003); error bars (only shown for $\mathrm{NaOH}$-extractable inorganic $\mathrm{P}$ ) indicate uncertainties in age estimation (Lair et al., 2009b); trend lines were fitted to fractions that showed a statistically significant age trend $(p<0.05)$, i.e. organic $\mathrm{P}$ and $\mathrm{HCl}$-extractable inorganic $\mathrm{P}$, respectively.

Hawaii. In the latter study, primary mineral $\mathrm{P}$ comprised about $80 \%$ of total $\mathrm{P}$ at a 300 -yr-old site, about $60 \%$ at a 2100-yr-old site, and decreased to $1 \%$ after 20000 years of pedogenesis. Unfortunately, the initial several hundred years of weathering and soil formation were not well resolved in this study. In a chronosequence study on Vancouver Island (MAT $=9.2^{\circ} \mathrm{C}, \mathrm{MAP}=3200 \mathrm{~mm}$ ), Singleton and Lavkulich (1987) observed an exponential decline of primary mineral $\mathrm{P}$ from about $350 \mathrm{mg} \mathrm{kg}^{-1}$ in the sandy parent sediments to about $10 \mathrm{~m} \mathrm{~kg}^{-1}$ in the upper $10 \mathrm{~cm}$ of a 550 -yr-old soil. In our study, we found a similar exponential dissolution pattern of HCl-extractable IP with a loss of approximately $300 \mathrm{mg} \mathrm{kg}^{-1}$ over approximately 600 years (Fig. 3), albeit under much drier climatic conditions.

\subsection{Dissolution kinetics of primary mineral phosphorus}

The HCl-extractable IP contents of the studied island soils (mean \pm standard deviation: $590 \pm 80 \mathrm{mg} \mathrm{kg}^{-1}$ ) closely matched those of 20 suspended flood sediment samples collected in the Danube main channel between 1990 and 2006 $\left(581 \pm 59 \mathrm{mg} \mathrm{kg}^{-1}\right.$; Zehetner et al., 2008). For the present study, we calculated mean area-based dissolution rates of $\mathrm{HCl}$-extractable IP using the mean $\mathrm{HCl}$-extractable IP content of the island soils (site 1) as starting point and bulk density for weight-to-volume conversion: 


$$
\begin{aligned}
& {\left[(\mathrm{HCl} \text {-extractable IP })_{\text {site } 1}-(\mathrm{HCl} \text {-extractable IP })_{\text {site }}\right]} \\
& \quad \times \mathrm{BD}_{\text {site }} \times \mathrm{D}_{\text {site }} \div(\text { soil age })_{\text {site }}
\end{aligned}
$$

where BD is soil bulk density and D is the layer thickness $(10 \mathrm{~cm})$.

The mean $\mathrm{HCl}$-extractable IP dissolution rates decreased exponentially with increasing soil age (Fig. 4). Schlesinger et al. (1998) determined HCl-extractable IP release rates from volcanic ash of between 0.05 and $0.22 \mathrm{~g} \mathrm{~m}^{-2} \mathrm{yr}^{-1}$ during 110 years of tropical weathering on Krakatau $\left(\mathrm{MAT}=27^{\circ} \mathrm{C}\right.$, $\mathrm{MAP}=2500-3000 \mathrm{~mm}$ ). At a soil age of approximately 100 years, we estimate the mean $\mathrm{HCl}$-extractable IP dissolution rates in the Danube floodplain soils at approximately $0.50 \mathrm{~g} \mathrm{~m}^{-2} \mathrm{yr}^{-1}$ (Fig. 4), i.e. almost an order of magnitude higher than on Krakatau.

The high $\mathrm{pH}$ values of the studied soils $(\mathrm{pH}>7$; Table 1) do not favour apatite dissolution, which generally increases with decreasing $\mathrm{pH}$ (e.g. Guidry and Mackenzie, 2003; Chairrat et al., 2007); nor do the relatively dry climatic conditions, as apatite dissolution has been reported to be several times faster at far-from-equilibrium conditions (which would be expected in a high-leaching environment) compared to near-equilibrium conditions (Guidry and Mackenzie, 2003). But what is the cause for the high dissolution rates of primary mineral P in the Danube floodplain soils? The latter authors concluded that apatite dissolution was surfacecontrolled rather than diffusion-controlled. Indeed, close relationships have been reported between apatite surface area and dissolved $\mathrm{P}$ in soil-water extracts (Kuo et al., 2009), and apatite dissolution rates have been found to be inversely related to grain size (Abu-Hilal et al., 2008). A reason for the rapid primary mineral $\mathrm{P}$ dissolution during the initial 100 years of soil formation in our study area could therefore lie in the fine grain sizes on the Danube floodplain (Table 1), which are the result of sedimentation under low flood water velocities. Between 200 and 600 years of soil formation, the mean $\mathrm{HCl}$-extractable IP dissolution rates decreased to between 6 and $2 \%$ of the initial rates (Fig. 4), reflecting the exhaustion of readily soluble (fine-grained) primary mineral $\mathrm{P}$ sources. An additional explanation for the initially high rates decreasing with soil age could be different solubilities of primary phosphates exhibiting different degrees of carbonate substitution (Guidry and Mackenzie, 2003).

\subsection{Temporal redistribution of copper among biogeo- chemical pools}

The sum of the five sequentially extracted $\mathrm{Cu}$ fractions (Tessier et al., 1979) varied between approximately 20 and $35 \mathrm{mg} \mathrm{kg}^{-1}$ (i.e. in the average range of non-polluted soils; Alloway, 1999), with no consistent age trend but significant differences between study sites (Table 1). These differences are likely due to slight variations in the $\mathrm{Cu}$ contents of the

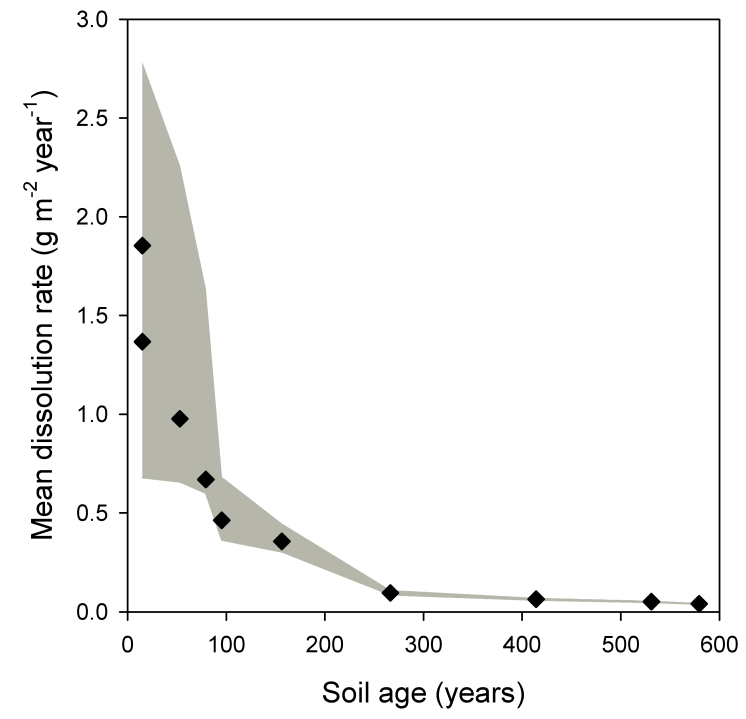

Fig. 4. Mean dissolution rates of $\mathrm{HCl}$-extractable inorganic $\mathrm{P}$ (Pardo et al., 2003) along the floodplain soil chronosequence (0$10 \mathrm{~cm}$ depth); shaded area indicates uncertainty of calculated dissolution rates due to uncertainties in age estimation (Lair et al., 2009b).

parent sediments. In the following, we therefore did not compare absolute amounts of extracted $\mathrm{Cu}$ fractions between sites, but rather followed their relative distribution across the studied chronosequence (Fig. 5).

Fraction A (exchangeable, weakly sorbed $\mathrm{Cu}$ ) ranged from 1 to $3 \%$ of total extracted $\mathrm{Cu}$ and did not show a significant age trend (Fig. 5). Fraction B (sorbed or carbonate-bound $\mathrm{Cu}$ ) made up between 8 and $13 \%$ of total extracted $\mathrm{Cu}$ in the youngest soils, however, decreased rapidly during the initial years of soil formation. The decreasing trend continuously leveled off during the following centuries of pedogenesis (Fig. 5). This exponential decrease closely matches the dissolution pattern of HCl-extractable IP, described in Sect. 4.1 (Fig. 3), which shows that carbonate-bound $\mathrm{Cu}$ and $\mathrm{HCl}$-extractable IP may be associated with one another in recently deposited sediments, or at least similar processes may be operating in their dissolution.

Fraction $\mathrm{C}(\mathrm{Cu}$ strongly bound to easily reducible $\mathrm{Mn}$ oxides and amorphous Fe oxides) accounted for 11 to $19 \%$ of total extracted $\mathrm{Cu}$ and did not change consistently with soil age (Fig. 5). Fraction D (Cu very strongly bound or incorporated into organic matter or other oxidizable species) made up a considerable portion of total extracted $\mathrm{Cu}$, ranging from 30 to $39 \%$, and did not show a significant age trend either (Fig. 5). While OP accumulation mirrored $\mathrm{HCl}$-extractable IP dissolution (Fig. 3) and essentially followed the accumulation of OC (Table 1), Cu in fraction D did not increase along with the dissolution of carbonate-bound $\mathrm{Cu}$ and the accumulation of $\mathrm{OC}$ across the chronosequence. A reason for this could be that $\mathrm{Cu}$ in fraction $\mathrm{D}$ may not only originate from organic matter. 


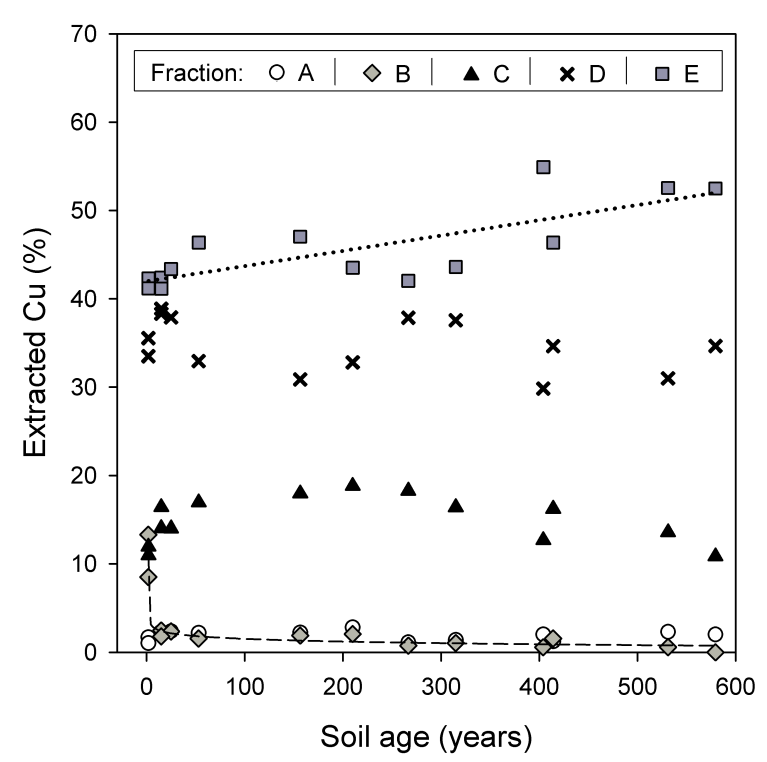

Fig. 5. Distribution of copper among biogeochemical pools along the floodplain soil chronosequence $(0-10 \mathrm{~cm}$ depth); $\mathrm{Cu}$ extraction according to Tessier et al. (1979): (A) $1 \mathrm{M} \mathrm{MgCl}_{2}$ (exchangeable, weakly sorbed), (B) $1 \mathrm{M} \mathrm{NaOAc}$ (sorbed or carbonatebound), (C) $0.04 \mathrm{M} \mathrm{NH}_{2} \mathrm{OH} \cdot \mathrm{HCl}$ in $25 \% \mathrm{HOAc}$ (strongly bound to easily reducible $\mathrm{Mn}$ oxides and amorphous $\mathrm{Fe}$ oxides), (D) $0.02 \mathrm{MHNO}_{3}+30 \% \mathrm{H}_{2} \mathrm{O}_{2}$ (very strongly bound or incorporated into organic matter or other oxidizable species), (E) $65 \% \mathrm{HNO}_{3}$ at $140^{\circ} \mathrm{C}$ (incorporated within resistant minerals); trend lines were fitted to fractions that showed a statistically significant age trend $(p<0.05)$, i.e. fractions $\mathrm{B}$ and $\mathrm{E}$, respectively.

Fraction $\mathrm{E}(\mathrm{Cu}$ incorporated within resistant minerals) was the dominant fraction in all studied soils (41 to 55\% of total extracted $\mathrm{Cu}$ ) and showed a linear increase with soil age (Fig. 5). This increase represents a relative enrichment of immobile $\mathrm{Cu}$ (at a rate of $0.017 \% \mathrm{yr}^{-1}$ ) due to the stability of the minerals extracted in this fraction. In the course of weathering and soil formation, $\mathrm{Cu}$ may so become enriched relative to more mobile elements. For example, Poulton and Raiswell (2000) found $\mathrm{Cu}$ enrichment (relative to $\mathrm{Al}$ ) in the sediments of eight world rivers, which, the authors concluded, was likely caused by accumulation of residual $\mathrm{Cu}$ in weathered topsoil layers that supply the riverine particulate load.

\section{Summary and conclusions}

Six hundred years of weathering under dry continental climate $\left(\mathrm{MAT}=9^{\circ} \mathrm{C}, \mathrm{MAP}=550 \mathrm{~mm}\right.$ ) have not resulted in notable changes of bulk or clay mineralogy. However, we found considerable (mostly non-linear) redistribution of $\mathrm{P}$ and $\mathrm{Cu}$ among biogeochemical pools. Calcium-associated $\mathrm{P}(\mathrm{HCl}-$ extractable IP) and $\mathrm{Cu}$ (fraction $\mathrm{B}$ ) decreased rapidly during the initial decades of soil formation, with trends continu- ously leveling off in the following centuries. The dissolution of calcium-associated $\mathrm{P}$ was accompanied by accumulation of OP. Copper incorporated within resistant minerals (fraction E) showed a relative enrichment with soil age. Mean dissolution rates of calcium-associated (primary mineral) $\mathrm{P}$ decreased exponentially with increasing soil age, and the initial rates (first century of pedogenesis) were almost an order of magnitude higher than rates reported for tropical environments. A reason for this could lie in the fine grain sizes on the Danube floodplain, providing readily soluble (fine-grained) primary mineral $\mathrm{P}$ sources.

Our results demonstrate that under moderate weathering conditions, considerable biogeochemical redistribution can take place within the first centuries of floodplain soil formation. Rapid dissolution of calcium-associated fractions mobilizes nutrients and metals and makes them temporarily bioavailable and susceptible for solute transport in the soilgroundwater-river system. This process supplies $\mathrm{P}$ for primary production, which is a prerequisite for the rapid $\mathrm{C}$ accretion observed in such ecosystems (Zehetner et al., 2009).

Acknowledgements. This work was supported by the European Union FP6 Integrated Project AquaTerra (Project no. GOCE 505428) under the thematic priority "sustainable development, global change and ecosystems". Additional support came from the Danube Regional Project Component 4.3 funded by UNDP/GEF. We are grateful to Christian Baumgartner (Nationalpark DonauAuen $\mathrm{GmbH}$ ) for the fruitful cooperation, to Winfried E. H. Blum for facilitating this research, and to Helene Pfalz-Schwingenschlögl for graphical support.

Edited by: K. Küsel

\section{References}

Abu-Hilal, A., Rasheed, M., and Al-Najjar, T.: Potential environmental impact of dissolution of raw phosphate in sea water of the Gulf of Aqaba, Chem. Ecol., 24, 51-59, 2008.

Adair, E. C., Binkley, D., and Andersen, D. C.: Patterns of nitrogen accumulation and cycling in riparian floodplain ecosystems along the Green and Yampa rivers, Oecologia, 139, 108-116, 2004.

Alloway, B. J.: Heavy Metals in Soils, Halsted Press, New York, 1999.

Bühl, A.: SPSS 16. Einführung in die Moderne Datenanalyse, 11th ed., Pearson Studium, Munich, Germany, 2008.

Chaïrat, C., Schott, J., Oelkers, E. H., Lartigue, J.-E., and Harouiya, N.: Kinetics and mechanism of natural fluorapatite dissolution at $25^{\circ} \mathrm{C}$ and $\mathrm{pH}$ from 3 to 12 , Geochim. Cosmochim. Acta, 71, 5901-5912, 2007.

Crews, T. E., Kitayama, K., Fownes, J. H., Riley, R. H., Herbert, D. A., Mueller-Dombois, D., and Vitousek, P. M.: Changes in soil phosphorus fractions and ecosystem dynamics across a long chronosequence in Hawaii, Ecology, 76, 1407-1424, 1995.

Cross, A. F. and Schlesinger, W. H.: A literature review and evaluation of the Hedley fractionation: applications to the biogeochem- 
ical cycle of soil phosphorus in natural ecosystems, Geoderma, 64, 197-214, 1995.

Decker, K., Peresson, H., and Hinsch, R.: Active tectonics and Quaternary basin formation along the Vienna Basin transform fault, Quaternary Sci. Rev., 24, 305-320, 2005.

Dorronsoro, C. and Alonso, P.: Chronosequence in Almar River fluvial-terrace soil, Soil Sci. Soc. Am. J., 58, 910-925, 1994.

Du Laing, G., Rinklebe, J., Vandecasteele, B., Meers, E., and Tack, F. M. G.: Trace metal behaviour in estuarine and riverine floodplain soils and sediments: a review, Sci. Total Environ., 407, 3972-3985, 2009.

Eash, N. S. and Sandor, J. A.: Soil chronosequence and geomorphology in a semi-arid valley in the Andes of southern Peru, Geoderma, 65, 59-79, 1995.

Engel, S. A., Gardner, T. W., and Ciolkosz, E. J.: Quaternary soil chronosequences on terraces of the Susquehanna River, Pennsylvania, Geomorphology, 17, 273-294, 1996.

Graf, M., Lair, G. J., Zehetner, F., and Gerzabek, M. H.: Geochemical fractions of copper in soil chronosequences of selected European floodplains, Environ. Pollut., 148, 788-796, 2007.

Guidry, M. W. and Mackenzie, F. T.: Experimental study of igneous and sedimentary apatite dissolution: control of $\mathrm{pH}$, distance from equilibrium, and temperature on dissolution rates, Geochim. Cosmochim. Acta, 67, 2949-2963, 2003.

Haslinger, E., Ottner, F., Lair, G. J., and Gerzabek, M. H.: Bulk and clay mineralogy of stream sediments of the rivers Danube, Ebro and Elbe, in: Beiträge zur Jahrestagung Valkenburg, edited by: Stanjek, H., 4-6 October 2006, Berichte der Deutschen Ton- und Tonmineralgruppe 12, 12-13, 2006.

Huggett, R. J.: Soil chronosequences, soil development, and soil evolution: a critical review, Catena, 32, 155-172, 1998.

Kaye, J. P., Binkley, D., and Rhoades, C.: Stable soil nitrogen accumulation and flexible organic matter stoichiometry during primary floodplain succession, Biogeochemistry, 63, 1-22, 2003.

Kendrick, K. J. and Graham, R. C.: Pedogenic silica accumulation in chronosequence soils, Southern California, Soil Sci. Soc. Am. J., 68, 1295-1303, 2004.

Kuo, Y.-M., Harris, W. G., Muñoz-Carpena, R., Rhue, R. D., and Li, Y.: Apatite control of phosphorus release to runoff from soils of phosphate mine reclamation areas, Water Air Soil Pollut., 202, 189-198, 2009.

Lair, G. J., Graf, M., Zehetner, F., and Gerzabek, M. H.: Distribution of cadmium among geochemical fractions in floodplain soils of progressing development, Environ. Pollut., 156, 207214, 2008.

Lair, G. J., Zehetner, F., Khan, Z. H., and Gerzabek, M. H.: Phosphorus sorption-desorption in alluvial soils of a young weathering sequence at the Danube River, Geoderma, 149, 39-44, 2009a.

Lair, G. J., Zehetner, F., Hrachowitz, M., Franz, N., Maringer, F.-J., and Gerzabek, M. H.: Dating of soil layers in a young floodplain using iron oxide crystallinity, Quat. Geochronol., 4, 260-266, 2009b.

Lair, G. J., Zehetner, F., Fiebig, M., Gerzabek, M. H., van Gestel, C. A. M., Hein, T., Hohensinner, S., Hsu, P., Jones, K. C., Jordan, G., Koelmans, A. A., Poot, A., Slijkerman, D., Totsche, K. U., Bondar-Kunze, E., and Barth, J. A. C.: How do long-term development and periodical changes of river-floodplain systems affect the fate of contaminants? Results from European rivers, Environ. Pollut., 157, 3336-3346, 2009c.
Leigh, D. S.: Soil chronosequence of Brasstown Creek, Blue Ridge Mountains, USA, Catena, 26, 99-114, 1996.

Mann, P. S.: Introductory Statistics, 6th ed. John Wiley \& Sons, Hoboken, NJ, USA, 2007.

Mehra, O. P. and Jackson, M. L.: Iron oxide removal from soils and clays by dithionite-citrate systems buffered with sodium bicarbonate, Clay Clay Min., 7, 317-327, 1960.

Mukherjee, A. B. and Bhattacharya, P.: Arsenic in groundwater in the Bengal Delta Plain: slow poisoning in Bangladesh, Environ. Rev., 9, 189-220, 2001.

Murphy, J. and Riley, J. P.: A modified single solution method for the determination of phosphate in natural waters, Anal. Chim. Acta, 27, 31-36, 1962.

Nordt, L. C., Hallmark, C. T., Wilding, L. P., and Boutton, T. W.: Quantifying pedogenic carbonate accumulations using stable carbon isotopes, Geoderma, 82, 115-136, 1998.

Pardo, P., López-Sánchez, J. F., and Rauret, G.: Relationships between phosphorus fractionation and major components in sediments using the SMT harmonised extraction procedure, Anal. Bioanal. Chem., 376, 248-254, 2003.

Poulton, S. W. and Raiswell, R.: Solid phase associations, oceanic fluxes and the anthropogenic perturbation of transition metals in world river particulates, Mar. Chem., 72, 17-31, 2000.

Schlesinger, W. H., Bruijnzeel, L. A., Bush, M. B., Klein, E. M., Mace, K. A., Raikes, J. A., and Whittaker, R. J.: The biogeochemistry of phosphorus after the first century of soil development on Rakata Island, Krakatau, Indonesia, Biogeochemistry, 40, 37-55, 1998.

Schwertmann, U.: Differenzierung der Eisenoxide des Bodens durch Extraktion mit Ammoniumoxalat-Lösung, Z. Pflanzenernaehr. Dueng. Bodenkd., 105, 194-202, 1964.

Shaw, J. N., Odom, J. W., and Hajek, B. F.: Soils on quaternary terraces of the Tallapoosa River, Central Alabama, Soil Sci., 168, 707-717, 2003.

Singleton, G. A. and Lavkulich, L. M.: Phosphorus transformations in a soil chronosequence, Vancouver Island, British Columbia, Can. J. Soil Sci., 67, 787-793, 1987.

Soil Survey Staff: Soil Survey Laboratory Methods Manual, Soil Survey Investigations Rep., 42, USDA - NRCS, Washington, DC, 2004.

Tabatabai, M. A. and Bremner, J. M.: Automated instruments for determination of total carbon, nitrogen, and sulfur in soils by combustion techniques, in: Soil Analysis, edited by: Smith, K. A., Marcel Dekker, New York, 261-286, 1991.

Tessier, A., Campbell, P. G. C., and Bisson, M.: Sequential extraction procedure for the speciation of particulate trace metals, Anal. Chem., 51, 844-850, 1979.

Van Cleve, K., Dyrness, C. T., Marion, G. M., and Erickson, R.: Control of soil development on the Tanana River floodplain, interior Alaska, Can. J. For. Res., 23, 941-955, 1993.

Vanek, A., Boruvka, O., Drabel, M., Mihaljevic, M., and Komarek, M.: Mobility of lead, zinc and cadmium in alluvial soils heavily polluted by smelting industry, Plant Soil Environ., 51, 316-321, 2005.

Vidic, N. J. and Lobnik, F.: Rates of soil development of the chronosequence in the Ljubljana Basin, Slovenia, Geoderma, 76, 35-64, 1997.

Walker, T. W. and Syers, J. K.: The fate of phosphorus during pedogenesis, Geoderma, 15, 1-19, 1976. 
White, A. F., Blum, A. E., Schulz, M. S., Bullen, T. D., Harden, J. W., and Peterson, M. L.: Chemical weathering rates of a soil chronosequence on granitic alluvium: I. Quantification of mineralogical and surface area changes and calculation of primary silicate reaction rates, Geochim. Cosmochim. Acta, 60, 25332550, 1996.

Williams, J. D. H., Jaquet, J. M., and Thomas, R. L.: Forms of phosphorus in the surficial sediments of Lake Erie, J. Fish. Res. Bd. Can., 33, 413-429, 1976.
Williams, J. D. H., Mayer, T., and Nriagu, J. O.: Extractability of phosphorus from phosphate minerals common in soils and sediments, Soil Sci. Soc. Am. J., 44, 462-465, 1980.

Zehetner, F., Lair, G. J., Maringer, F.-J., Gerzabek, M. H., and Hein, T.: From sediment to soil: floodplain phosphorus transformations at the Danube River, Biogeochemistry, 88, 117-126, 2008.

Zehetner, F., Lair, G. J., and Gerzabek, M. H.: Rapid carbon accretion and organic matter pool stabilization in riverine floodplain soils, Global Biogeochem. Cy., 23, GB4004, doi:10.1029/2009GB003481, 2009. 